
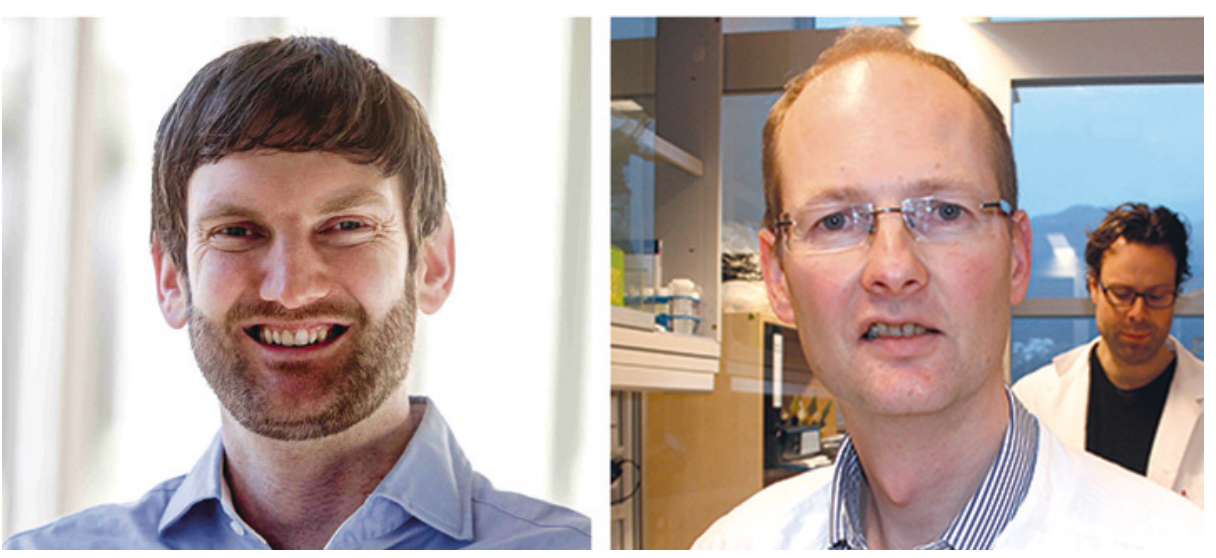

Til venstre: andreforfatter Simon Dankel. Foto: Chad Kline, KPC Media Group. Til høyre: medforfatter Gunnar Mellgren. Foto: Øyvin Eng. Haukeland universitetssykehus

\title{
Ny genetisk mekanisme for type 2-diabetes påvist
}

Den genetiske bakgrunnen for type 2-diabetes er i stor grad knyttet til regulatoriske DNA-elementer. Dette viser en internasjonal studie der norske forskere har spilt en viktig rolle.

Kun $2 \%$ av vårt DNA består av proteinkodende sekvenser, dvs. det vi kaller gener. Resten består av såkalt ikke-kodende DNA. $\mathrm{Vi}$ vet lite om funksjonen til denne delen av vårt genom. Norske forskere har nylig bidratt til en studie som har funnet nye funksjoner i det ikke-kodende DNA (1).

Ved metoden som ble anvendt ser man etter komplekse mønstre i ikke-kodende DNA som er felles for mennesket og andre dyrearter. Når samme DNA-mønstre er konservert i flere arter, tyder det på at disse DNA-områdene har en viktig biologisk funksjon. Blant annet har det vist seg at slike deler av DNA kan påvirke aktiviteten av gener i den proteinkodende delen av DNA og skru gener av og på.

For å se om metoden kan brukes til å finne nye sykdomsmekanismer undersøkte forskerne et DNA-område som ligger i nærheten av genet $P P A R G$-genet, som påvirker insulinfølsomhet og hvordan celler i fettvev håndterer glukose og fett. Endringer i aktiviteten av $P P A R G$-genet er knyttet til risiko for type 2-diabetes. Det viste seg at hvis en bestemt DNA-sekvens i nærheten av $P P A R G$-genet hadde en genetisk variant (polymorfisme), ble danningen av PPARG-protein fra PPARG-genet påvirket slik at omsetningen av glukose og fett ble forstyrret.

- Denne studien gir holdepunkter for at arvelige mekanismer for $ø$ kt diabetesrisiko primært finnes i DNA-områder som regulerer genuttrykk, sier Simon Dankel, andreforfatter av artikkelen og postdoktorstipendiat ved Universitetet i Bergen og Hormonlaboratoriet, Haukeland universitetssykehus.
- De samme DNA-sekvensene fantes i nærheten av flere ulike risikogener for type 2-diabetes, noe som kan tyde på at en felles mekanisme kan forklare hvorfor disse genene disponerer for type 2-diabetes.

- Kunnskap om disse regulatoriske områdene i DNA kan brukes til å utvikle nye strategier for forebygging eller behandling av sykdom, sier medforfatter Gunnar Mellgren, som er professor og overlege ved Hormonlaboratoriet, Haukeland universitetssykehus og leder av forskningsgruppen ved K.G. Jebsen-senter for diabetesforskning ved Universitetet i Bergen.

\section{Internasjonalt diabetessamarbeid}

Studien er et resultat av internasjonalt samarbeid. Målet er å identifisere faktorer som er viktige for utvikling av type 2-diabetes og fedme. Simon Dankel og Gunnar Mellgren er en del av K.G. Jebsen-senter for diabetesforskning ved Universitetet i Bergen. Dankel har samarbeidet tett med førsteforfatter Melina Claussnitzer ved Technische Universität München, som har utviklet den matematiske algoritmen i studien. Fettvev fra pasienter ble samlet inn ved bl.a. Voss sykehus, Haraldsplass diakonale sykehus og Klinikk Bergen.

\section{Kari Tveito}

Tidsskriftet

\section{Litteratur}

1. Claussnitzer M, Dankel SN, Klocke B et al. Leveraging cross-species transcription factor binding site patterns: from diabetes risk Loci to disease mechanisms. Cell 2014; 156: 343-58.
Ordforklaringer:

Proteinkodende DNA: DNA-sekvensene i genomet som gir opphav til nye proteiner i cellene, utgjør mindre enn $2 \%$ av total mengde DNA. De fleste genetiske sykdomsmekanismer som er påvist, ligger i denne delen av DNA.

Ikke-kodende DNA: De resterende $98 \%$ av DNA som ikke koder for proteiner, der man hittil har funnet få eksempler på genetiske sykdomsmekanismer.

Regulatorisk DNA: Sekvenser i ikke-kodende DNA der proteiner kan binde slik at proteinkodende gener slås av eller på. 